\title{
6. Dingo scalping and the frontier economy in the north-west of South Australia
}

\author{
DIANA YOUNG
}

\section{Introduction}

Responding to the threat from the dingo to pastoral stock, in 1912, the South Australian Government passed the Wild Dogs Act. Later, in the 1920s, there were similar schemes introduced in Western Australia and the Northern Territory (Gara 2005). In reframing the dingo as a commodity, materialising its value through the presentation of its skin as a 'scalp' and offering a bounty for it, the legislation created specific conditions for encounters between Aboriginal people in the far north-west of South Australia and the settlers in the form of the bushmen who pursued that bounty and who came to be known as 'doggers'. For Anangu (Pitjantjatjara and Yankunytjatjara people), the term 'scalp' did not exist; it was and is still simply the skin of the dog: papa miri. ${ }^{1}$

Anangu did not wear animal skins on their bodies before contact with the settlers or utilise them in any systematic way except perhaps by using kangaroo skins as water bags (Young 2010). Instead it was the extrusions from skin-hair and fur - that every Anangu knew how to spin into string, which served to attach and reattach people and was one of a range of things used in exchange. My wider argument concerning skins points to the evidence that its potentiality was elaborated after contact with settlers and their goods and, as I argue here, in part by the commodification of dingo skin.

Through the colonists' bureaucratic reframing of dingo as vermin because of their threat to lambs (and to a lesser extent sheep), the lives of Aboriginal people still remote from the main areas of settlement would be changed. The commodification of the dingo's skin was in large measure responsible for the

1 Anangu means 'person' in Pitjantjatjara, and is used as a contemporary way of naming themselves by Pitjantjatara and Yankunytjatjara people. It was not used in this way during the period under discussion here. 
establishment of the Presbyterian Mission, for its siting at Ernabella and for the subsequent ability of Anangu to travel widely across country. The skin of the dingo was in summary an example of Webb Keane's exhortation to ask, 'what do things make possible?' Through the medium of the dingo skins, it is possible to discern specific distributions of power (Miller 2005:18).

\section{Dogging and the getting of goods}

Anapala was a place on Yankunytjatjara land nestled among ranges that the explorer Ernest Giles had named the Musgraves. It had a permanent waterhole and good run-off from the surrounding hills. It was a fecund, important place for Aboriginal people, rich in game and hence a good place for dingo, too. In the years of the Great Depression, it began to attract doggers. Here is Walter Smith, a bushman of some Aboriginal ancestry, telling Dick Kimber about a 1924 dogging trip:

That Ernabella country was the best place, mate. God, talk about dingoes there. Caves there, you know and they go there mating time. All the dogs go there plenty of water about nice springs. Plenty of rabbits, wallabies and euros too for a feed for themselves and when the pups are born. (Kimber 1996:48-9)

On Walter Smith's 1924 dogging trip, all scalps - whether of pups, bitches or dogs - were worth $7 \mathrm{~s} 6 \mathrm{~d}$. The doggers took steel axes and steel knives to exchange with Anangu for scalps: 'They just take that scalp for us, and cook him then' (Kimber 1996:48-9; see also Harney 1969:159; Tindale 1974:23).

In parting the dingo from its skin, Aboriginal people kept the meat for themselves and seem later to have concealed this consumption of dingo from the Ernabella missionaries. ${ }^{2}$ Harney (1969:159) reported that the 'succulent pups' were cooked after their skin was removed to sell. I consulted Gordon Ingkatji on this point at Ernabella in 2009 (Field notes, 22 September 2009, 26, 4). He was at pains to point out that before white people came Anangu ate only papa inyuru (wild dogs), not camp dogs. Puppies, he said, are kuka wiru, 'lovely meat': 'You don't eat the really young ones but when they walk. You take the skins and cook him after, cut open the tjuni [stomach] and put itara [bloodwood] leaves inside - salt wiya [no salt].' 'How did you skin them?' I asked. He ran a finger

\footnotetext{
2 Anangu stopped eating pups perhaps during the early 1950s. Certainly, the Ernabella Mission staff from this era did not seem aware that Anangu ate pups. See also Harney (1969), quoting Minyinderri (1963:160). Earlier accounts by visitors to the mission in the late 1930s noted that Aboriginal people ate pups.

3 Salt (wiya) applies to all the important Tjukurpa (Dreaming Ancestor) species of animal when Anangu consume them as meat.
} 
across his upper lip: 'You cut across here or maybe above the eyes and round the neck and down the witapi [spine] and take the ears and tail.' In other words, the papa miri was the whole underside of the animal along with its tail.

Before the advent of the doggers, pups were a delicacy that Anangu cooked in their skins - as they did and still do with almost all other bush animals. The cook scorches off the fur and blackens the skin before the animal is cooked in a fire-pit oven. Yielding the dingo's skin to outsiders created cash and access to settler goods. The dingo had a far greater capacity when its surface and interior were made partible.

In 1920, the Pitjantjatjara country of the Petermann Ranges and the Uluru area were gazetted as the Peterman, North West and Central Australian Reserves (Layton 1986:72), but it was not policed by the authorities nor was there a ration station established inside it. Doggers were able to penetrate it with impunity. The reserve area was seen as a breeding ground for dingo that would harm the adjacent pastoral leases, and rather than shooting dingo or killing them with traps baited with strychnine, as was usual, the doggers found Aboriginal labour a better option (Gara 2005:1). Their hunting skills and habitat knowledge yielded a greater return of scalps and the doggers paid the hunters in goods: commonly flour, sugar and tobacco - the 'stimulants' that Stanner (1965) noted Aboriginal people 'craved' and would travel for. Obtaining clothing too was an incentive for Aboriginal people to engage in the dingo trade. H. H. Finlayson famously wrote that 'scalps were a sort of currency' (Rowse 1998:60); I return to the materiality of that currency later.

The doggers attracted large numbers of Anangu to their seasonal camps, desirous of the goods they could get for the dingo skins. Individual doggers often returned to the same base camp year after year, aiming to establish good relations with local Anangu. The police acted as the government agents who remunerated the doggers with cash. The local depot for such transactions was Oodnadatta to the east on the edge of the Simpson Desert, where there were pastoral leases already operating.

In 1933, the anthropologist Norman Tindale noted in his field journal that the doggers were exerting a huge attraction for Anangu, who were travelling and camping in large numbers with individual doggers. Tindale had difficulty finding natives to travel with him to Ernabella because of the draw of the doggers, although ironically he had employed as a guide and camel driver the dogger Alan Brumby (Tindale 1933). The incentive to travel with the anthropologist must have been, one can imagine, far less than the allure of staying with the dogger. Tindale (1933) wrote: 
Indigenous Participation in Australian Economies

The doggers have runners out and are attempting to hold as many natives as possible; we may have an uphill go to get natives to Ernabella. (p. 567)

Propaganda by the dogger who has been competing for the services of the natives, has caused them to fear. (p. 605)

Jack Anderson, a dogger was camped at Konapandi [Kunapanti] and leaves for Ernabella accompanied by 27 natives. (p. 621)

\section{The establishment of the mission at Ernabella}

The confluence of desires - for scalps on the part of the doggers and for goods on the part of Anangu - gave rise to concern from parties who considered that the European doggers were ill-educated low-life corrupting the last intact natives on the continent. This perception was in reality not so easily defined. There were a number of men with Aboriginal ancestry (Walter Smith and Tommy Dodd, for example) who took up dogging. 'Contamination' of the native was by Afghans, too, as Albrecht noted (Redmond and Skyring, this volume; Rowse 1998). By 1930, the activity of doggers had transformed Ernabella Soak, as it was known in English, into a settler depot of sorts at the end of the Oodnadatta mail run. It was a place of organised contact between doggers and Anangu who came to barter their dingo skins (Elkin 1931:44; Hilliard 1968:95).

Visiting anthropologists, Elkin in 1930 and Tindale in 1933, the Hermannsburg missionaries, scout for the Presbyterian Mission Board J. R. B. Love and Charles Duguid all expressed concern to the Aborigines Protection Board and the South Australian Government. Duguid was a Scottish doctor of medicine who set out to visit the Musgraves in 1935 at the suggestion of Pastor Albrecht at Hermannsburg. One of the critical factors for Duguid in wanting to set up a mission in the area was the presence of doggers. Another was the steady drift of Aboriginal people from the region towards Oodnadatta. It is probable that Oodnadatta had become known among Anangu at least partly because of the doggers of 'the Musgraves and Great Central Aborigines reserve':

These people have all seen aeroplanes or motor cars and have come in contact with white men who, for years, have trespassed on the Reserve. They have become curious and are anxious to see beyond their old horizons. It is because they have been coming into the settled white civilization that we have gone out to meet them. (Duguid 1939)

After R. M. Williams made two dogging trips through the Mann, Musgrave, Rawlinson and Warburton ranges in 1928, returning to Oodnadatta with hundreds of scalps, he inspired other men working on the same pastoral station 
circuits north-west of Oodnadatta to do the same (Williams 1998:62). Among them were Harold Brown, Alan Brumby, Paddy De Conley and Charlie Lester. All these men went on to become pastoralists. They were the first non-Aboriginal people to really live with Anangu. Both Brown and Brumby had their names appropriated as last names by Anangu, as did De Conley as 'Connally'. ${ }^{4}$ Harry Brumby, Alan's father, seems to have given his name to, or had it appropriated by, a Yankunytjatjara/Wirtjapakanja man who worked with Bill Harney and had his own camels.

Harold Brown and Alan Brumby had started out as partners in about 1929 making their first trip to the Musgrave and Mann ranges and Uluru (Gara 2005:3, quoting Terry 1932). Both had Aboriginal children with wives whom they subsequently abandoned (see also Gara 2005). As Redmond and Skyring note (this volume), 'white men's relationships with Aboriginal women were central to the operation of the frontier economy'. Harold Brown was killed with his non-Aboriginal wife when the bedroom roof of their mud house at Shirley Well (Officer Creek), near present-day Fregon, collapsed (Harney 1969:170; Hilliard 1968). Harney dates this event as 1939. Their house girl was Eileen Stephens, the Pitjantjatjara woman who recently found fame at the end of her life as a painter; she died in 2008.

In the 1940s, De Conley established a pastoral lease at Mt Conner (Layton 1986:67) after working as a stockman at Kulgera, where he was charged with owner, Bert Kitto, with murdering an Aboriginal employee; they were acquitted (Gara 2005:6). Among the drawings that Charles Mountford collected, made by Anangu at Ernabella in 1940, there are several concerning the poisoned flour episode. One by a young woman called Ada relates how the dogger Paddy De Conley left behind flour laced with strychnine. Ada said that two men and one boy died as a result of eating the flour, with this event taking place in about October $1936 .{ }^{5}$

In order to secure their rights to the dingoes and exclude others, the doggers purchased the leases on surrounding blocks of land, becoming putative pastoralists, using the proceeds of the skins. There was a government scheme that rewarded any pastoralist who sank a bore with $£ 200$ and 100 square miles (260 sq km) of land at peppercorn rent (Gara 2005:3). Brumby was the nephew of one Stan Ferguson, also a one-time dogger who had, in 1933, sunk a well at Ernabella Soak and stocked the new station with 2000 sheep and 200 goats (Hilliard 1968). Ernabella Station was thus officially established that year.

4 Cf. Toby Nganina on 'Paddy Connally' from Layton's fieldwork (1986:67) and the Connally family at Kalka/ Pipalytjara.

5 Ada, 6th October 1940 Ernabella, Mountford Collection Drawings, vol. 2, part 7, nos 101-16, State Library of South Australia, Adelaide. 
Ferguson's son recalled his father's life in 1996. Ferguson had worked at Macumba Station, having migrated during the Depression years from Broken Hill in New South Wales to Oodnadatta. He married an Aboriginal woman there and set up Granite Downs Station with Charlie Lester, the father of wellknown Yankunytjatjara activist Yami Lester. Next, Ferguson set up a station at Mooralinya - now the Anmuryinna Homeland, west of Indulkana on the Anangu Pitjantjatjara Yankunytjatjara lands. From there, Ferguson moved his family to develop Kenmore Park Station, selling it to George Fraser and moving on in 1933 to Ernabella. Here, according to his son, he wished to settle down, but eventually in 1936, the Presbyterian Church managed to negotiate a price with him and purchased the station as a going concern with its livestock and the homestead he had built. ${ }^{6}$

Ernabella was an excellent site for the mission with its potable waters and idyllic setting; also a draw were an existing well and a sturdily built homestead that remains to this day. The homestead was also just outside the reserve and Duguid intended it as a buffer for Aboriginal people between the pastoral world beyond it and the country to its west in the reserve. It was of course also intended as a gateway that kept 'unscrupulous whites' at bay.

In September 1936, Duguid (1963:52) finally persuaded the Presbyterian Church of Australia's Board of Missions to pass a motion to set up a mission at Ernabella. An important decision was made by the Mission Board to rid the area of the intrusive doggers (the doggers who were in effect using Aboriginal labour to dispossess those same people of their land). The natives would receive the full government subsidy for scalps either in the form of cash or exchanged for goods at the Ernabella Mission store. ${ }^{7}$ Thus, by the time the Ernabella Mission was founded, Anangu were well acquainted both with white people and with their goods. The flow of novel goods was mediated by dingo scalping and the relationships it created. Love notes of the doggers in his journal of 1937 (p. 6) that 'the goods used in trade include flour, tea, sugar, tobacco, matches, shirts and trousers, and dresses. The question whether [they] ought to be clothed has been partly, and unfavourably, decided already by the doggers.'

The goods had to be desirable to Anangu otherwise they were useless as payment. If the 'question of clothing' was already decided in large measure by Anangu who had seen its capacities and potentials well before the Ernabella Mission began, so too was an idea of labouring for those goods; they were not the hand-outs for no labour that Duguid despised in government ration depots. Labouring for goods or for a combination of goods ('rations') and wages was the foundation of the Ernabella Mission ethic. Clothing had already become, even

6 Interview with Donald Ferguson, 1996, Ara Iritija Archive, m1015.

7 The mission did retain 2s as a handling charge in the mid-1950s to early 1960s (Sheppard 2004). 
as rags, an essential exchange item among Aboriginal people themselves and one that was and is subject to 'demand sharing' — the practice of demanding a portion of resources that sustains or creates social ties, in the same way as food (Peterson 1993).

By 1940, there were still doggers in the reserve. 'Every main water I go there are deep camel pads, made by these doggers', notes Mountford (1940:1069). The doggers were flouting the law, not just by entering the land, but, knowing the difficulty of policing the reserve, by cohabiting with Aboriginal women (Gara 2005). Mountford fulminated in his field journal:

I personally have told the Protector of Aborigines in Adelaide that doggers were going everywhere, and he said he did not want to know. The Anthropological Society wrote protesting, and the Protector replied 'that he had not been asked for permission to enter the reserve for the last 5 years'. (Mountford 1940:1069)

Although Duguid could boast in 1941 that the mission exerted control over the South Australian section of the Great Central Reserve, he wanted a camel patrol partly to police intruders, citing Laverton as the entry point for many doggers. ${ }^{8}$

\section{Consumption}

The Protestant Presbyterian Ernabella Mission, although exceptional in many ways, was like other such missions - and not only in Australia: intent on attempting to control discernment in consumption practices as an aspect of civilising and desirous of helping people to use those goods in particular ways, not least as personal property and as self-enhancement (Comaroff 1996). The point that cultures are constructed through consumption is a moot one here.

The new Ernabella Mission had an immediate problem-one that continued to haunt mission correspondence for decades to come-namely, that once Aboriginal people came into the mission, they had to want to use it as their preferred base, to make it their ngura/place or home. There was no compulsion to stay. As the missionaries knew, especially at the start, the gospel teachings alone could not hope to anchor people to the place. Wages were paid largely in goods; these commodities had to compete with those at the surrounding depots, stations and missions - goods that would make Ernabella desirable to Aboriginal people.

8 Letter, Duguid to Chinnery, 1 August 1941, BOEMAR records, Mitchell Library, Sydney. 
In 1948, a mission report suggests that the Ernabella Mission cash store should maintain a wider range of goods than at present, 'so as to encourage the scalp trade and more frequent visits by bush natives' ${ }^{9}$ Clothing could now be bought in the Ernabella Mission store either with wages or with the proceeds of the scalps. The cash subsidy for a scalp was now £1. ${ }^{10}$ In 1946, Haasts Bluff-formerly a pastoral lease but then a new reserve and an outstation of the Hermannsburg Mission-received '853 dingo scalps' but had also traded '3171 kangaroo skins'. At Areyonga, another Hermannsburg outpost, 748 dingo scalps and 571 kangaroo skins were received, with a $6 \mathrm{~d}$ handling charge on the scalps being deducted. According to Harney, the bounty price for dingo differed between Western Australia and the Northern Territory; it was worth 10s in the latter, 'but three times that amount in WA'.

\section{Sheep and dingo}

Kimber (1996:48) notes that the linkage in Aboriginal thought between sheep and dingo is evinced by the fact that the southern Arrernte at first used the term for dingo ('unguina') for sheep, as the dingo has a bushy tail similar to the woolliness of sheep. ${ }^{11}$ Sheep went inexorably together with dingo since no use was made of fences (Rowse 1998). Where there were sheep or goats there had to be 24-hour shepherding to protect them from the depredations of dingoes. Rowse discusses how scalping and shepherding were interlinked occupations for Aboriginal people around the Central Desert stations Tempe Downs, Loves Creek and Henbury. This pattern was reproduced around Ernabella. Long before there were 'outstations', there were sheep camps around Ernabella. By 1940, there were many livestock run on the mission; 'sheep counted 29/1/40, 1441 , goats plus kiddies 202, camels $8^{\prime} .{ }^{12}$

The mission instituted a well-sinking program that augmented those already existing from the doggers' efforts as pastoralists. ${ }^{13}$ Sheep camps were made around wells. Shepherding was an ideal occupation for people who had just 'come in' from the bush. Here, a family group could live together for several months at a time with a reliable supply of water, augmenting their rations as wages of flour, tea and sugar with bush foods and perhaps with dingo scalping.

\footnotetext{
9 Ibid.

10 Ernabella Mission, General Secretaries' Visit, 2 November, V. W. Coombes 1948, BOEMAR records, Mitchell Library, Sydney.

11 Harney (1969:155) writes that camels were given the name for dogs: 'we call camel Puppanarri.'

12 Letter, Mr Ward to Dr Duguid, 7 February 1940, Ernabella, BOEMAR records, Mitchell Library, Sydney, p. 1. Ward's list concludes: 'Horses. Not seen here regularly but all here I think except the stallion which I shot and the people ate.'

13 Cf. Ian Dunlop (1962), showing an Ernabella-based man, Louis, with a well-sinking business. Earlier wells were dug out by hand.
} 
When I lived on the Anilalya Homelands in 1997 and 1998, my constant companions - Anangu then in their sixties, seventies and eighties - unfailingly pointed out the old wells and sheep camps to me, naming then as we passed, as doubtless they had to other incomers. Turners Well, for example, is a favourite honey ant hunting location and Youngs Well remains a homeland. One of the last conversations I had with Billy Wara (d. November 2008), whose portrait features in Hilliard's book as a boy who gave figs to Lasseter (the lost white explorer who died of starvation because he refused the food offered by local people), was about the sheep camps and the shearing iriti ('in the old days') (Hilliard 1968). In tandem with the recollection by older Anangu of the sheep camps ('use sheep shit for your garden', people told me, 'it's the best', even though there were no sheep left in 1997, nor had there been since the mid1970s) was that of pupping_papa miri time.

Sheep wool was the economic basis of the mission, sent through the Finke rail stop to Adelaide, but two sheep a day were butchered for meat since there was no refrigeration and the skins from these were also sold (Edwards interview, 1 July 2008). It was also by spinning the sheep fur/inyu-analogous to the spinning of other animal fur and human hair pre-contact - that the Ernabella women provided the basis for the Ernabella craft room. This is another aspect of frontier economy that began in 1948 but one that I am unable to explore here.

By 1958, when the Ernabella store was still receiving scalps and selling supplies, better provision was required for the storage of both dingo and sheep skins. ${ }^{14}$

\section{Spatio-temporal dingo skins}

When the piriya - a warm wind that has been loosely equal to 'spring time' blows and the Seven Sisters appear again in the eastern sky at dawn with their lascivious male pursuer, Wati Nyiru, or in non-Aboriginal terms, Orion and the Pleiades, Anangu know that the dingo pups are being born. Harney (1969:158) calls the Pleiades the 'dog stars', as the dingo has seen them before Anangu. This is a rewarding time to be out collecting food from the bush, after winter rains. The mission sheep shearing also took place at this time, employing local men. At the close of shearing, the shearers were paid off, each receiving a little extra cash (Edwards interview, 1 July 2008).

Anangu then went travelling - indeed, were encouraged by the mission to do so, in order that they used the reserve. Anangu refer to this time, when talking about it now, as 'holidays' (also Harney 1969:159). They left the mission to hunt

14 Australian Presbyterian Board of Missions Report of Inspection of Ernabella Mission by Rev. G. Anderson and Rev. H. M. Bell, September 1958, BOEMAR records, Mitchell Library, Sydney. 
for dogs and perhaps visit their own country (see White, this volume, for a similar seasonal pattern among Aboriginal people in New South Wales). It was a way of showing country to children. Successfully hunting for dingo skins enabled the travel, providing both the means and the end.

At this time, the missionaries would close up the craft room and the school since they were governed not by the Education Department calendar but by the mission calendar. Bill Edwards was then acting mission superintendent. In 2008, he recalled:

[T]hey [Anangu] could buy a big bag of flour and sugar and distribute it and they would get on their camels and head out and we would arrange to meet them before they left...they might say, 'look in two weeks can you be at Amata [then Musgrave Park Station]?' or somewhere west of Amata so we would arrange to take flour, sugar, tins of things and we would meet them. 1958 - [my] first year - we went west of Amata and people would line up on the road with their dingo pup skins and trade these for things we had such as tins of powder[ed] milk for the babies and so on.

...The people would go about their own business and so forth and gradually come back and we would open the school and the craft room again. We might come back with 150 to 200 scalps.

...People might work for a month (for example as shepherds) and get 11 10s and for five dingo pups...£5 so that was a lot of money. You could get a $60 \mathrm{lb}$ bag of sugar or a $150 \mathrm{lb}$ bag of flour for $£ 5$ at the mission store. So that was a precious commodity. (Edwards interview, 1 July 2008)

During that period of three months' shepherding contract men got a shirt and a pair of trousers, and women [who were paid less] got printed material every six weeks or three months two and a half yards or, if they were a little larger, three yards and they would make their own dresses with that. (Edwards interview, 1 July 2008)

The establishment of a camp for tourists at Uluru in the late 1950s provided work for Anangu, cooking and making beds and enabling further such employment for Aboriginal people along the tourist route in from Alice Springs (Interview with Amanyi [Dora] Haggie [Okai], Ernabella, August 2008). Barbara Nipper's mother made beds for the tourists in Bill Harney's time (late 1950s to early 1960s). Barbara Nipper's husband (Nipper Winmati) worked cutting firewood. At weekends, they would go out using one camel to Kata Tjuta, Titirarra Rockhole, Impumpu, Mantarur, Puta Puta, Tjunti or Docker River, hunting dingo skins. Two dingo skins were worth $£ 1$. They received 2 s from tourists for camel rides. Peter Severin of Curtin Springs pastoral lease paid them 
money for the scalps. Some places would buy the skins only with rationsgolden syrup, jam, sugar, and so on-not with money (Barbara Nipper, Peter Sutton field book, 88:230-1).

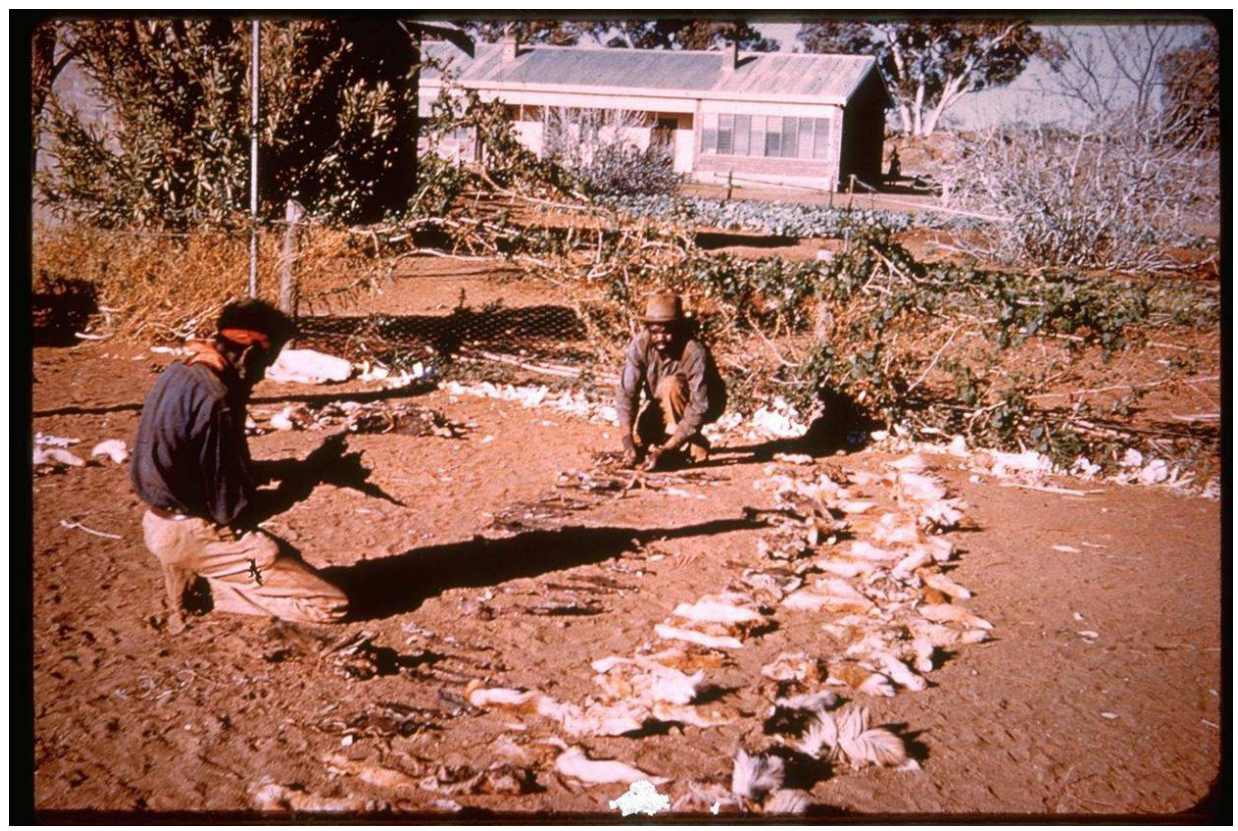

\section{Figure 6.1 Sorting dingo skins at Ernabella 1957}

Ara Irititja Project, Collection Uniting Church (Vic), photographer Bruce Edenborough, Ernabella $1957 .{ }^{15}$

The film Camels and the Pitjantjatjara was made at Curtin Springs and shows people setting off to get dingo skins (Sandell 1969). In 1954, the Ernabella Choir, a group of young people, went to Adelaide to see the Queen. They sold dingo scalps to finance their own trip (Carell and Dean 1955).

So, between the 1940s and the 1960s, pupping was a perfect occupation for Anangu. There was no 'boss' as there was in pastoral and mission work. To a large extent, you could choose to whom you surrendered the skins and thereby what you received in return. The number of dingoes was still expanding and the bounty went up accordingly. There was some complaint that Aboriginal people were 'farming dingo' by only getting the pups and not the adults (cf. Sheppard 2004:39). As Sheppard notes, the 'farming' accusation was almost certainly true. To address this, in the mid-1960s, the bounty was changed to $£ 2$ ( $\$ 4$ ) for a big scalp and only 10s (\$1) for a pup (Edwards interview, 1 July 2008).

15 The man with the red headband is Ngulitjara, the father of Robert Stevens. The other Pitjantjatjara man is the father of Munti Smith. 


\section{The materiality of dingo skin as commodity}

Although for some decades the dingo skin was a currency common to doggers, missionaries, station owners and Aboriginal people alike, the effectiveness of that currency and people's attitudes to its materiality varied between them.

The dingo is, according to the women who taught me, a 'watiku miilmiilpa Tjukurpa' - a secret, sacred Dreaming that belongs to men. According to Ingkatji in 2009, it is a Tjukurpa, which belongs to both men and women. This variation in who tells what and how is ubiquitous in Western Desert cultures where men's and women's roles in ceremony are complementary. One can extrapolate from these two statements that the dingo is a Tjukurpa belonging to men and thus women cannot speak directly about it although an individual may be knowledgeable (ninti), and that there are non-secret aspects to the Dreaming (Wallace 1990:89). A more delineated case of taboo is that of the kangaroo. In the 1960s, when the craft women made shoes from kangaroo skins to sell to the settler market, they were forbidden by their men to use local kangaroo skin (Hilliard 1968). Malu (kangaroo) is, however, more definitely watiku ('belonging to men'). For the dingo to be skinned was, however, acceptable; both men and women could handle the skins.

For the mission staff, the dingo skins were not dense enough in their materiality; they were easily counterfeited or recycled. It is said that corrupt police, who were the handlers of the skins, could with a certain amount of ingenuity claim them twice and double the money. Anangu too tried this, according to the then mission superintendent: 'you had to watch this - you lined up the scalps and someone could come along and sell them back again from the other end of the line' (Edwards interview, 1 July 2008). The pup skins were accepted for payment if the whole thing from the ears down to the tail was presented-a small scalp fully materialised. For the mature dogs, the police would accept the two joined ears and the tail as separate - a rather more immaterial version of a dingo. Anangu could manufacture dingo 'ears' by sewing up pieces of skin (Edwards interview, 1 July 2008). This playfulness or trickster element in creating 'ears' in the scalp trade is analogous to certain contemporary woodcarving amendments. For example, spear throwers' timber and quartz blades are joined together using a resin made from spinifex grass - a resin that is labour intensive to produce. Nowadays, the resin can be creatively imitated by melting black rubbish sacks to produce a similar-looking, though not similar-smelling, substance.

During the 1960s, punu (artefacts) replaced dingo skins as the principal source of independent income for Aboriginal groups (Layton 1986:80) - due in part to the Uluru tourist trade. Rose (1965:68) notes that in the early 1960s the Angas Downs artefact trade, where Anangu were trading directly with tourists, made 
about $£ 2$ a week whereas a four-week dogging trip yielding 14 scalps provided 5 guineas a week (Rose 1965:71, cited in Layton 1986:81). Both were seasonal, since tourists came mostly during the cooler winter months and pupping took place in the spring.

\section{Conclusions}

Dogging was important for several reasons. It provided the impetus to begin the mission at Ernabella to protect Annangu from exploitation by the doggers. It was, however, mostly through the doggers that Anangu first gained access to nonAboriginal goods, and the Presbyterian Church had the foresight to understand how this could be used to fulfil the mission's aims. Going out for dingo skins, west into the reserve, stopped Anangu travelling to settled areas, justifying the reserve's existence, and at the same time fulfilled the desire of Anangu to acquire European things. Collecting dingo skins enabled people to travel back to their own country, earning money, acquiring food and other goods as they went along. The dingo skins were wealth in many ways and it is no wonder that papa miri is remembered with such fondness by older people now.

I want to emphasise here the importance of the dingo trade in the development of a 'frontier economy' where it was far from a marginal activity but one that lasted for 40 years, but also the materiality of the skins as a mediating currency that contributed to different forms of objectification for Aboriginal people.

In more recent (and erudite) accounts of Indigenous central Australians, settler goods remain secondary in a large part because they have been understood by anthropologists as being in the service of relatedness and ultimately disposable in that service. Working with Indigenous consultants at Hermannsburg, AustinBroos $(2006: 29$, 2009) concludes that 'money is...rendered as a thing in the service of relatedness'. In Peterson's (1993) influential paper on demand sharing in Indigenous Australia, she writes that Aboriginal people 'tend to assimilate the meaning of commodities and cash to this mode of social relations'. Myers (1988), writing of the community outstation truck, also concludes that the truck for Pintupi is just a thing in the same service and could thus be disposed of by burning it to prevent further demands on the person who held its key. Others have argued that Aboriginal societies are economies in which services are the things exchanged, so that the materiality of the objects is not crucial (Merlan 1991). There is an idea that things themselves carry a capitalist and colonial ideology within them, following Lukacs (1971; Redmond 2006; Rowse 1998; Stotz 2001), but that somehow the materiality of those things is irrelevant or at the very least secondary to their role as mediators. Critiques of materialism, as Daniel Miller (2006:343) has pointed out, often assume that such an approach 
imposes 'a mistaken emphasis on objects as opposed to persons' - that is, to focus on materialism denigrates the attachment of persons rather than in fact serving to reattach them in creative ways through the specific qualities of things.

The dingo skin, once separated from the flesh of the dingo, achieved a seemingly neutral liminal status that enabled it to become currency between Aboriginal people, between settlers and across cultures. Yet it cannot have been a neutral thing that had the same meaning for all the trading parties. With the skins, Anangu acquired settler commodities and through these began to remake their world just as those goods remade them. Dingo skins were locally produced and became the outward flow of trade networks whose incoming goods included foodstuffs, axes and clothing. The socio-temporal life of things in motion, linking people and contexts, requires also a 'critical fetishism' to help elucidate the nuances of value creation of both things and people (Appadurai 1986, 1990; Foster 2006; Kopytoff 1986; Munn 1986). Addressing the dingo's skin in various contexts is inadequate in the task of teasing out its value to Aboriginal people. The skins were derived from a very animate source: an important Dreaming animal that was part of country, not an imported commodity. Did Anangu understand dingo scalping to be 'giving' an objectification of their culture to the various settlers: doggers, missionaries, pastoralists? Was this an act that was 'at once a declaration of one's own value and an engagement with the recipient' (Myers 2002:5), as the woodcarvings and paintings that they later made became?

Some time during the early period of contact with the settler economy, cloth, ready-bought yarns and clothing became valuable to Aboriginal people. Accumulating clothing is now, and has been since at least the 1950s, a means of accumulating wealth; it is used as payment in ritual throughout many areas of Aboriginal Australia. I am not suggesting that trading dingo skins for clothes, as Anangu often did, was conceived by them as a tight symbolic connection, exchanging surface for surface, although this could have been the case. I am arguing that the surface of things and persons - and thing-like persons and person-like things - became increasingly important after contact when the means to elaborate surfaces became available. Attwood (1989:20), writing of the colonisation of an Aboriginal group in New South Wales, finds that there was an 'early Aboriginal perception that clothes and bodies of whites were inseparably joined'.

Among Anangu in the Western Desert, the same moment occurred-50 or so years later. Cloth quickly becomes conceived of as skin-like and is valued for that reason since it is a material that easily makes bodies mutable (Young 2010). Clothes became an aspect of personhood. Western Desert Aborigines reconfigure themselves through wearing coloured cloth that materialises their connections both to one another and to their country, whose surface is mutable, especially chromatically mutable (Young forthcoming). Clothing is, however, also a 
partible aspect of personhood. Hair-string becomes reserved for specialist ritual use and although it continues as an exchange item it is too labour intensive to compete with the imported cloth and yarns. At the same time, the skin of the dingo becomes routinely separated from its body and circulates, attracting other goods in return. These skins that served as currency were also the adornment of the dingo.

For hunter-gatherer people concerned with the minutiae of practices and appearances, it is likely that Anangu found similarities between the outbound dingo skins and the incoming cloth and the possibilities of political power that each could exert. This might be termed an economy of surfaces - one that leads to new forms of objectification among Aboriginal people.

\section{Acknowledgments}

I have used a combination of recollection and archival documents in this essay. I wanted to include the recollections of those who lived through this era-an era that is on the cusp of being conjured only through media.

Thank you to Anangu for teaching me since 1996, especially the Stanley and Windlass families and to Gordon Ingkatji. Warm thanks to Bill Edwards for generously allowing me to tape an interview with him and for his comments on the essay. Thanks to Peter Sutton for access to his research for the Yulara Native Title claim. Thanks to John Dallwitz at the Ara Irititja Archival Project and to BOEMAR for allowing me access, in 2003, to the records of the Uniting Church on the Ernabella Mission and for permission to quote from them. The British Academy funded this research trip from the United Kingdom to Australia in 2003.

\section{References}

Appadurai, A. 1986, 'Introduction: commodities and the politics of value', in A. Appadurai (ed.), The Social Life of Things: Commodities in cultural perspective, Cambridge University Press, UK.

Appadurai, A. 1990, 'Disjuncture and difference in the global economy', Public Culture, vol. 2, no. 2, pp. 1-24.

Attwood, B. 1989, The Making of the Aborigines, Allen \& Unwin, Sydney.

Austin-Broos, D. 2006, "Working for" and "working": the Western Arrernte in kin-based and market-based society', Oceania, vol. 76, no. 1, pp. 1-15. 
Indigenous Participation in Australian Economies

Austin-Broos, D. 2009, Arrernte Present, Arrernte Past: Invasion, violence, and imagination in Indigenous Central Australia, University of Chicago Press, Ill.

Carell, Victor and Dean, Beth 1955, Dust for the Dancers, Ure Smith, Sydney.

Comaroff, J. 1996, 'The empire's old clothes, fashioning the colonial subject', in D. Howes (ed.), Cross Cultural Consumption, Routledge, London and New York, pp. 19-38.

Duguid, C. 1939, The Medical Patrol, Pamphlet, Ernabella Mission, South Australia.

Dugiud, C. 1963, No Dying Race, Rigby, Adelaide.

Dunlop, I. (dir) 1962, The Aborigines of Australia, Film, Commonwealth Film Unit (Screen Australia), Sydney.

Elkin, A. P. 1931, 'The social organisation of South Australian tribes', Oceania, vol. 2, pp. 44-73.

Foster, R. 2006, 'Tracking globalisation. Commodities and values in motion', in P. Spyer, C. Tilley, S. Kuechler and W. Keane (eds), The Handbook of Material Culture, Sage Publications, Thousand Oaks, Calif., pp. 285-302.

Gara, T. 2005, 'Doggers in the north west', History Matters, vol. 15, no. 2, pp. $8-10$.

Harney, B. 1969 [1963], To Ayers Rock and Beyond, Rigby Ltd/Seal Books, Adelaide.

Hilliard, W. 1968, The People In Between, Hodder and Stoughton, London.

Kimber, R. G. 1996, The Man from Arltunga. Walter Smith Australian bushman, The Arltunga Hotel and Bush Resort and Hesperian Press, Alice Springs, NT, and Carlisle, WA.

Kopytoff, I. 1986, 'The cultural biography of things', in A. Appadurai (ed.), The Social Life of Things: Commodities in cultural perspective, Cambridge University Press, UK, pp. 64-91.

Layton, R. 1986, Uluru: An Aboriginal history of Ayers Rock, Aboriginal Studies Press, Canberra.

Love, J. R. B. 1937, Diary of a visit to Ernabella to establish a Presbyterian Mission, 24th May to 24th October 1937, Manuscript, State Library of South Australia, Adelaide. 
Lukacs, G. 1971, History and Class Consciousness: Studies in Marxist dialectics, Translated by R. Livingstone, Merlin Press, London.

Merlan, F. 1991, 'Women. Productive roles and the monetisation of the service mode in Aboriginal Australia: perspectives from Katherine, Northern Territory', Australian Journal of Anthropology, vol. 2, pp. 259-92.

Miller, D. 2005, 'Introduction', in D. Miller (ed.), Materiality, Duke University Press, Durham, NC, and London, pp. 1-50.

Miller, D. 2006, 'Consumption', in P. Spyer, C. Tilley, S. Kuechler and W. Keane (eds), The Handbook of Material Culture, Sage Publications, Thousand Oaks, Calif., pp. 341-54.

Mountford, C. P. 1940, Journal of an expedition to the north west of South Australia, [2 vols], State Library of South Australia, Adelaide.

Munn, N. 1986, The Fame of Gawa. A symbolic study of value transformation in a Massim (Papua New Guinea) society, Duke University Press, Durham, NC, and London.

Myers, F. 1988, 'Burning the truck and holding the country: property, time and the negotiation of identity among Pintupi Aborigines', in T. Ingold, D. Riches and J. Woodburn (eds), Hunter Gatherers Today, Berg, Oxford, pp. $52-74$.

Myers, F. 2002, Painting Culture. The making of an Aboriginal High Art, Duke University Press, Durham, NC, and London.

Peterson, N. 1993, 'Demand sharing: reciprocity and the pressure for generosity among foragers', American Anthropologist, (NS) vol. 95, no. 4, pp. 860-74.

Redmond, A. 2006, 'Further on up the road: community trucks and the moving settlement', in T. Lea, E. Kowal and G. Cowlishaw (eds), Moving Anthropology: Critical Indigenous studies, Charles Darwin University Press, Darwin, pp. 95114.

Rose, F. G. G. 1965, The Wind of Change in Central Australia. The aborigines of Angas Downs. Akademie Verlag, Berlin.

Rowse, T. 1998, White Flour, White Power: From rations to citizenship in Central Australia, Cambridge University Press, UK.

Sandell, R. (dir) 1969, Camels and the Pitjantjatjara, Film, Australian Institute of Aboriginal Studies, Canberra. 
Sheppard, N. 2004, Sojourn on Another Planet, Nancy Sheppard, Collinswood, SA.

Stanner, W. E. H. 1965 [1958], Continuity and change, Presidential address to Section F. (Anthropology), Australian and New Zealand Association for the Advancement of Science, Adelaide, 1958, [Reprinted in Stanner, W. E. H., White Man Got No Dreaming, University of Chicago Press, Ill., and London].

Stotz, G. 2001, 'The colonizing vehicle', in D. Miller (ed.), Car Cultures, Berg, Oxford and New York, pp. 223-44.

Tindale, N. B. 1933, Journal of an anthropological expedition to the Mann and Musgrave ranges north west of South Australia May-July 1933 and a personal record of the anthropological expedition to Ernabella 1933, Manuscript, South Australia Museum, Adelaide.

Tindale, N. B. 1974, Aboriginal Tribes of Australia: Their terrain, environmental controls, distribution, limits, and proper names, University of California Press, Berkeley.

Wallace, N. 1990, 'The religion of the Aborigines of the Western Desert', in M. Charlesworth, R. Kimber and N. Wallace (eds), Ancestor Spirits: Aspects of Australian Aboriginal life and spirituality, Deakin University Press, Geelong, Vic., pp. 48-92.

Williams, R. M. 1998, A Song in the Desert, Angus and Robertson, Pymble, NSW.

Young, D. 2010, 'Clothing in the Western Desert', in Joanne Eicher (ed.), The Encyclopaedia of World Dress and Fashion, Berg, Oxford.

Young, D. (forthcoming), 'Mutable things: colours as material practice in the north west of South Australia', Journal of the Royal Anthropological Institute. 